\title{
Lipid Profile and Fatty Acid Composition of Two Silurid Fish Eggs
}

\author{
Tapas Mukhopadhyay and Santinath Ghosh* \\ Department of Chemical Technology, University of Calcutta (92, A.P.C. Road, Kolkata - 700 009, West Bengal, INDIA)
}

\begin{abstract}
The lipid content and the composition pattern of the lipid class including fatty acid composition in the eggs of two different Indian silurid cat fishes Ompok pabda and Wallagu attu have been examined. The lipid content of $O$. pabda and $W$. attu (on dry basis) are about $14.7 \%$ and $17.8 \%$ respectively. The major lipid classes are phospolipid (PL) and triacylglycerol (TAG). The $O$. pabda egg lipid contains more PL while the $W$. attu egg lipid contains more TAG. Phosphatidylcholine (PC) constitutes the major phospholipid followed by phosphatidylinositol (PI). PI represents in about $31.7 \%$ and $21.3 \%$ of total PC in $O$. pabda and $W$. attu respectively while phosphatidylethanolamine (PE) (about 28.0\%) is significantly higher in the egg of $W$. attu than $O$. pabda $(9.6 \%)$. Cholesterol content in egg of $O$. pabda is also higher (about 9.6\%) than W. attu (4.1\%). The lipids are rich in polyunsaturated fatty acids (PUFAs) and they are mainly concentrated in the respective PL fractions. Among PUFAs the arachidonic acid (20:4 n-6 AA) is present at about 9.3\% in both egg PL. Eicosapentaenoic acid (20:5 n-3 EPA) is significantly lower in egg lipids of both $W$. attu (1.8\%) and $O$. pabda (3.2\%), whereas docosahexaenoic acid (22:6 n-3 DHA) is predominantly higher (14.6\% and $18.1 \%$ in $W$. attu and $O$. pabda respectively) in their PL fractions.
\end{abstract}

Key words: fish egg, Ompok pabda, phospholipid, Wallagu attu

\section{INTRODUCTION}

$O$. pabda and W. attu are both fresh water silurid catfish. O. pabda is geographically distributed in Afghanisthan, Pakistan, North eastern states of India, Bangladesh and Burma, where as W. attu is mainly distributed in Pakistan, India, Srilanka, Nepal, Bangladesh, Burma, Thailand, Vietnam, Kampuchea, the Malaysia Peninsula, Sumatra and Java. Both of these two fishes inhabit rivers, tanks and ponds. W. attu is one of the largest, voracious and predatory of the local cat fishes. It is a premonsoon summer breeder. It is very destructive to other more valuable food fishes such as major carps like Catla, Roghu, Mrigel etc. It is rather sluggish and prefers to occupy in river bed in search of food ${ }^{1)}$.

Lipids are one of the most important components of fish eggs, providing energy reserves and components of cell bio-membranes ${ }^{2)}$. Triacylglycerol (TAG) is usually the primary form of energy storage in egg and yolksac larvae of many fish species ${ }^{3-4}$. The egg quality of fresh water fishes are often measured as hatchability and the parameters are related to the content of fatty acids ${ }^{5}$. The essential fatty acids (EFAs) present in the fish eggs are vital for early survival and development of newly hatched larvae ${ }^{6-7)}$.

Several researchers have worked on the lipid composition of fish eggs of marine and fresh water fishes and their probable correlation with the growth, fertilization and embryonic development in fish ${ }^{8-9}$. The chemical composition of eggs is often examined to evaluate egg quality, as the egg must satisfy nutritional needs for embryonic and larval development ${ }^{10-111}$. The lipid nutrition in fish suggests that certain larval stages require phospholipid (PL) in their $\operatorname{diet}^{12-13)}$ for proper development and growth.

The present study aims at, investigating the comparative lipid profile and fatty acid composition extensively to find out whether $O$. pabda and W. attu eggs contain any important fatty acid or lipid class components in significant proportion, their nutritional significance on the basis of essential fatty acids present in neutral lipid and PL fraction, and the same to assess the familial biochemical resemblances supporting the biochemical evidence of evolution.

\footnotetext{
* Correspondence to: Santinath Ghosh, Department of Chemical Technology, University of Calcutta, 92, A.P.C. Road Kolkata - 700 009, West Bengal, INDIA

E-mail: santinathghosh@yahoo.com.hk

Accepted May 8, 2007 (received for review April 3, 2007)
}

Journal of Oleo Science ISSN 1345-8957 print / ISSN 1347-3352 online

http://jos.jstage.jst.go.jp/en/ 


\section{MATERIALS AND METHODS}

\subsection{Sample collection}

Matured unfertilized eggs of six different gravid live females of both $O$. pabda and W. attu weighing about 0.29 $\mathrm{kg}$ and $7.2 \mathrm{~kg}$ respectively were collected from the Ganga river at Ranaghat, Nadia, W.B., India. O. pabda fishes were collected during monsoon breeding season but $W$. attu fish egg samples were collected during their premonsoon breeding season. The egg samples of both the fishes were stored in glass vials containing chloroform/methanol $(2: 1, \mathrm{v} / \mathrm{v})$ and $0.01 \%(\mathrm{w} / \mathrm{v})$ butylated hydroxytoluene $(\mathrm{BHT})$ at $-20^{\circ} \mathrm{C}$ prior to extraction.

\subsection{Lipid extraction}

The total lipid of egg samples was extracted separately by the method of Folch et al. ${ }^{14)}$. After extraction of lipid the chloroform layer was removed under a stream of nitrogen and finally the lipid was dried under vacuum and stored, in sealed dark amber glass containers at $-20^{\circ} \mathrm{C}$ until used for analysis.

\subsection{Lipid analysis}

\subsubsection{Lipid class composition analysis}

The isolated lipids of both eggs were mainly a mixture of PL, TAG, cholesterol, diacylglycerol (DG), monoacylglycerol (MG), hydrocarbon (HC) and waxester as identified distinctly on the thin layer chromatographic (TLC) plate (silica gel G; solvent system hexane/diethyl ether, 70:30 v/v) with phosphate stain, standard PL, cholesterol, TAG, waxester, DG, MG and HC.

Total PL content in egg lipid was estimated in terms of total phosphorous content by following Official Methods and Recommended Practice of A.O.C.S. ${ }^{15)}$. The total cholesterol content of egg was estimated according to the standard method of Zlatkis et al. ${ }^{16)}$. Wax ester and TAG was estimated by the standard column chromatographic method $^{17)}$ and DG, MG, hydrocarbon are expressed as other components by difference.

Major PL fractions like phosphatidylcholine (PC), phosphatidylinositol (PI) and phosphatidylethanolamine (PE) contents of egg PL were measured by A.O.C.S. Official Method and Recommended Practice ${ }^{15)}$. According to this method individual PL fractions like PC, PI and PE (major fractions) were measured by fractionation into two dimensional TLC followed by phosphorous measurement with the help of UV-spectrophotometer (UV-1601. Shimadzu Co. JAPAN).

The total fatty acid composition of the lipid and of the isolated TAG and PL were determined by Gas-liquid chromatography (GLC) method after derivatization into methyl esters as mentioned in our previous publication ${ }^{18)}$.

\subsection{Statisitical analysis}

The results are given as the mean \pm standard error of mean. For statistical analysis of results, student's t-test ${ }^{19}$ was performed.

\section{RESULTS AND DISCUSSION}

O. pabda and W. attu fish eggs from six different individuals were analysed separately and total lipid content and lipid class compositions are shown in Table 1. Mean wet weights of matured eggs of $O$. pabda and $W$. attu are $4.5 \%$ and $15 \%$ of the total weight of the matured adult fish respectively. The lipid content (on dry basis) in eggs of $W$. attu and $O$. pabda measured about $17.8 \%$ and $14.7 \%$ respectively.

The major portion of the egg lipid of both $O$. pabda and W. attu is composed of mainly PL and TAG. In O. pabda, $\mathrm{PL}$ content is $56.8 \%$, which is significantly higher than PL present in eggs of $W$. attu (28.6\%). TAG content both in $O$. pabda (29.5\%) and W. attu (38.4\%) egg lipid is the major fraction. Among the other lipid class components, cholesterol content in eggs of $O$. pabda (9.6\%) is significantly higher than in W. attu (4.1\%). Total amount of MG, DG and hydrocarbons expressed as others is significantly higher (27.5\%) in case of W. attu egg lipid than O. pabda egg lipid (2.2\%). Wax ester content is $3.2 \%$ in $O$. pabda and $1.3 \%$ in W. attu fish eggs.

PL present in the total lipid of both eggs is fractionated to determine the individual fractions (Table 2). In both eggs, the most abundant PL fraction is PC (about 58.7\% in O. pabda and about $50.6 \%$ in W. attu). PI is found to be the second major fraction about $31.7 \%$ and $21.3 \%$ in egg lipid of O. pabda and W. attu respectively followed by $\mathrm{PE}$ (at $9.6 \%$ and $28.02 \%$ respectively).

In the egg lipid of both fishes, $\mathrm{PC}$ is the predominant $\mathrm{PL}$ fraction. PC has long been known for its structural role in eggs. PC is also implicated as the source of very important metabolic precursors in eggs and larvae of marine species. In halibut plaice (Pleuronectes platessa) and turbot, $\mathrm{PC}$ is catabolised during embryogenesis, prior to first feeding ${ }^{9)}$. Fraser et $a l .{ }^{12)}$ also showed that PC was a source of metabolic energy and a source of essential fatty acids (EFAs), organic phosphorous in eggs and larvae of Cod, Gadus morhua. Evans et al. ${ }^{8)}$ showed that PC was playing an important role after fertilization for Atlantic halibut (Hippoglossus hippoglossus). High amount of PC in eggs of $O$. pabda and $W$. attu will definitely play a significant role during embryogenesis. PC appears to be crucial in the formation of very low-density lipoprotein (VLDL) during the intestinal absorption of neutral lipids and thus increases the amount of energy available for growth ${ }^{20-21)}$.

Table 3 lists the fatty acid compositions of total lipid, TAG and PL fractions in eggs of $O$. pabda and W. attu. Among the saturated fatty acids the most abundant is palmitic acid (16:0) both in W. attu and $O$. pabda total 
Table 1 Lipid Content and Lipid Class Composition in Eggs of Boal (Wallagu attu) and Pabda (Ompok pabda).

\begin{tabular}{lcc}
\hline & Wallagu attu & Ompok pabda \\
\hline Total weight of fish (wet weight) & $7.2 \pm 0.12(\mathrm{~kg})$ & $290.6 \pm 6.34(\mathrm{~g})$ \\
Weight of fish eggs (wet weight) & $1.1 \pm 0.08(\mathrm{~kg})$ & $13.2 \pm 1.55(\mathrm{~g})$ \\
Moisture content in fish eggs (\%) & $60.5 \pm 0.87$ & $62.1 \pm 2.51$ \\
Lipid content (\% dry weight) in eggs & $17.8 \pm 0.96$ & $14.7 \pm 1.74$ \\
Lipid class composition (\% w/w of total lipid) & & \\
Phospholipid (PL) & $28.6 \pm 1.03^{*}$ & $56.8 \pm 1.11^{*}$ \\
Cholesterol & $4.1 \pm 0.02^{*}$ & $9.6 \pm 0.62^{*}$ \\
Triacylglycerol (TAG) & $38.4 \pm 0.24^{*}$ & $29.5 \pm 0.63^{*}$ \\
Wax ester & $1.3 \pm 0.04$ & $3.2 \pm 0.27$ \\
Others (MG + DG + Fatty acid) & $27.5 \pm 0.02$ & $2.2 \pm 0.55$ \\
\hline
\end{tabular}

Values are mean $\pm \mathrm{SE}, \mathrm{n}=6 \quad * \mathrm{P}<0.001$

Table 2 Major Phospholipid Fractions (\% w/w of Total Phospholipid) in Eggs of Boal (Wallagu attu) and Pabda (Ompok pabda).

\begin{tabular}{lcc}
\hline Phospholipid fractions (\% w/w of total phospholipid) & $\boldsymbol{W}$. attu Eggs & $\boldsymbol{O} . \boldsymbol{p a b d a}$ Eggs \\
\hline Phosphatidylcholine (PC) & $50.6 \pm 1.32^{*}$ & $58.7 \pm 1.08^{*}$ \\
Phosphatidylinositol (PI) & $21.3 \pm 0.75^{*}$ & $31.7 \pm 0.94^{*}$ \\
Phosphatidylethanolamine (PE) & $28.0 \pm 0.43^{*}$ & $9.6 \pm 0.57^{*}$ \\
\hline
\end{tabular}

Values are mean $\pm \mathrm{SE}, \mathrm{n}=6 \quad * \mathrm{P}<0.001$

lipid. Palmitic acid in total lipid of $O$. pabda is significantly higher than that of the present in $W$. attu. Among the TAG and PL fractions, palmitic acid is mainly concentrated in the triglyceride fraction in both fish egg lipids. Total saturated fatty acid content in the $O$. pabda is significantly higher than in W. attu. Oleic acid is the major mono unsaturated fatty acids present both in those two fish egg lipids and mainly accumulated in the respective PL fractions. Total monounsaturates in the $W$. attu egg lipid is significantly higher than that of the present in $O$. pabda. 33.2\% PUFA is present in $O$. pabda, which is significantly higher than that present in W. attu (29.2\%). Among the PUFAs, linoleic acid and arachidonic acid (AA) are present as $n-6$ fatty acids where as eicosapentaenoic acid (EPA), docosapentaenoic acid (DPA) and docosahexaenoic acid (DHA) are present as major n-3 fatty acids both in $W$. attu and $O$. pabda. PUFAs are mainly concentrated in the respective PL fraction at a significant higher level in comparison with TAG fraction. The ratio of $\mathrm{n}-3$ to $\mathrm{n}-6$ fatty acids varies from 1.4 to 1.6 in case of $W$. attu and 2.1 to 3.2 in case of $O$. pabda.
It has been reported by other workers that fresh water fishes are able to desaturate and elongate dietary $\mathrm{C}_{18} \mathrm{n}-6$ and n-3 PUFAs to $\mathrm{C}_{20}$ and $\mathrm{C}_{22}$ desaturates ${ }^{22-23)}$. The present study also supports the previous observations that these two fresh water silurid catfishes are characterised by high proportions of $n-6$ and n-3 PUFAs in their egg lipid.

The comparative lipid profile in eggs of $O$. pabda and $W$. attu reveals that both the fishes belonging to the same family, Siluridae, are rich in PUFAs of which the major portion is concentrated in the PL fraction. Both eggs also accumulate EPA along with DHA, which are both considered essential for growth and survival of hatchlings. AA, which is also present at a significant level, has been implicated in prostaglandin formation in marine fish and eicosanoids produced from $\mathrm{n}-6$ fatty acids have a critical physiological role in gill, kidney, intestine and ovaries ${ }^{2,23)}$. The n-3 PUFAs, in general, have been suggested to be important in brain and nervous system development and in reproductive success in fresh water as well as in marine fish ${ }^{24)}$. It has also been suggested that n-3 PUFAs are catabolised during early development and that saturated 
Table 3 Fatty Acid Composition of Egg Lipid of Boal (Wallagu attu) and Pabda (Ompok pabda).

\begin{tabular}{|c|c|c|c|c|c|c|}
\hline \multirow[b]{3}{*}{ Fatty acids } & \multicolumn{6}{|c|}{ Fatty Acid Composition $(\% \mathrm{w} / \mathrm{w})$ in } \\
\hline & \multicolumn{3}{|c|}{ W. attu Egg Lipid } & \multicolumn{3}{|c|}{ O. pabda Egg Lipid } \\
\hline & TOTAL & TAG & PL & TOTAL & TAG & PL \\
\hline $14: 0$ & $0.8 \pm 0.34$ & $1.2 \pm 0.05$ & $0.8 \pm 0.04$ & $2.2 \pm 0.09$ & $11.5 \pm 0.18$ & $6.8 \pm 0.18$ \\
\hline $16: 0$ & $22.9 \pm 0.99^{*}$ & $28.3 \pm 0.05^{*}$ & $15.3 \pm 0.06^{*}$ & $36.0 \pm 0.36^{*}$ & $46.3 \pm 0.39^{*}$ & $25.6 \pm 0.14^{*}$ \\
\hline $18: 0$ & $12.5 \pm 0.42 *$ & $23.4 \pm 0.10^{*}$ & $9.3 \pm 0.04^{*}$ & $6.6 \pm 0.19^{*}$ & $2.7 \pm 0.09^{*}$ & $9.4 \pm 0.12 *$ \\
\hline 20:0 & $1.5 \pm 0.07$ & $0.7 \pm 0.08$ & $1.7 \pm 0.11$ & 0.0 & 0.0 & 0.0 \\
\hline TotalSaturates & $37.7 \pm 0.84$ & $53.7 \pm 0.02$ & $27.1 \pm 0.05$ & $44.9 \pm 0.34$ & $60.6 \pm 0.29$ & $41.8 \pm 0.21$ \\
\hline $14: 1$ & $0.3 \pm 0.02$ & $0.6 \pm 0.04$ & $0.22 \pm 0.05$ & 0.0 & 0.0 & 0.0 \\
\hline $16: 1$ & $5.9 \pm 0.72$ & $11.2 \pm 0.08$ & $2.5 \pm 0.06$ & $2.1 \pm 0.04$ & $5.5 \pm 0.16$ & $2.5 \pm 0.18$ \\
\hline $18: 1$ & $24.1 \pm 0.72$ & $15.5 \pm 0.05$ & $29.8 \pm 0.04$ & $18.5 \pm 0.60$ & $15.9 \pm 0.19$ & $17.7 \pm 0.19$ \\
\hline $20: 1$ & 0.0 & 0.0 & 0.0 & $1.8 \pm 0.17$ & $2.6 \pm 0.06$ & $1.1 \pm 0.09$ \\
\hline Total Mono Unsaturates & $30.3 \pm 0.02$ & $27.3 \pm 0.09$ & $32.6 \pm 0.05$ & $22.5 \pm 0.59$ & $24.1 \pm 0.33$ & $20.4 \pm 0.14$ \\
\hline $18: 2 n-6$ & $4.3 \pm 0.42$ & $2.7 \pm 0.08$ & $6.6 \pm 0.04$ & $1.8 \pm 0.24$ & $3.3 \pm 0.13$ & $2.1 \pm 0.07$ \\
\hline $20: 2 n-6$ & 0.0 & 0.0 & 0.0 & $0.3 \pm 0.03$ & $0.4 \pm 0.05$ & $0.4 \pm 0.04$ \\
\hline $20: 3 n-6$ & 0.0 & 0.0 & 0.0 & $0.4 \pm 0.04$ & $0.4 \pm 0.07$ & $0.3 \pm 0.06$ \\
\hline $20: 4 n-6$ & $6.9 \pm 1.05$ & $3.3 \pm 0.06$ & $9.3 \pm 0.05$ & $8.7 \pm 0.38$ & $1.5 \pm 0.16$ & $9.3 \pm 0.10$ \\
\hline $22: 4 n-6$ & $0.9 \pm 0.13$ & $0.6 \pm 0.04$ & $0.7 \pm 0.05$ & $1.1 \pm 0.04$ & $0.5 \pm 0.09$ & $0.7 \pm 0.06$ \\
\hline $20: 5 n-3$ & $1.4 \pm 0.06$ & $0.4 \pm 0.05$ & $1.8 \pm 0.05$ & $3.2 \pm 0.21$ & $1.3 \pm 0.10$ & $3.2 \pm 0.10$ \\
\hline $22: 5 n-3$ & $4.3 \pm 0.20^{*}$ & $2.3 \pm 0.06^{*}$ & $6.1 \pm 0.06^{*}$ & $2.7 \pm 0.14^{*}$ & $1.6 \pm 0.10^{*}$ & $2.8 \pm 0.90^{*}$ \\
\hline $22: 6 n-3$ & $11.3 \pm 0.85$ & $6.3 \pm 0.07$ & $14.6 \pm 0.04$ & $14.4 \pm 0.43$ & $6.4 \pm 0.07$ & $18.1 \pm 0.11$ \\
\hline Total PUFA & $29.2 \pm 0.66^{\#}$ & $15.7 \pm 0.09$ & $39.1 \pm 0.02$ & $33.2 \pm 0.47^{\#}$ & $15.4 \pm 0.44$ & $36.9 \pm 0.09$ \\
\hline (n-3)Total & $17.9 \pm 0.28^{*}$ & $9.6 \pm 0.18^{*}$ & $23.0 \pm 0.40^{*}$ & $22.1 \pm 0.26^{*}$ & $10.7 \pm 0.17^{*}$ & $25.5 \pm 0.31^{*}$ \\
\hline$(n-6)$ Total & $12.1 \pm 0.07$ & $6.6 \pm 0.16$ & $16.6 \pm 0.06$ & $12.3 \pm 0.20$ & $5.4 \pm 0.01$ & $12.8 \pm 0.19$ \\
\hline$(n-3) /(n-6)$ & $1.6 \pm 0.06^{*}$ & $1.5 \pm 0.13 *$ & $1.4 \pm 0.07^{*}$ & $2.1 \pm 0.03 *$ & $2.2 \pm 0.06^{*}$ & $3.2 \pm 0.04 *$ \\
\hline Others & $2.7 \pm 0.36$ & $3.2 \pm 0.07$ & $1.1 \pm 0.06$ & 0.0 & 0.0 & 0.0 \\
\hline
\end{tabular}

Values are mean $\pm \mathrm{SE}, \mathrm{n}=6 \quad * \mathrm{P}<0.001 \quad{ }^{*} \mathrm{P}<0.01$

fatty acids are used for energy production at later stages ${ }^{25)}$.

The egg lipid of $O$. pabda contains high amount of PL, which is very important for nutrition and its role in cell membrane development and healthy liver function. It is due to their high PL and low cholesterol content, the pabda fish eggs may be recommended for consumption by children and adults. The lipid profiles including fatty acid compositions of the two different kinds of fish belonging to the same family, Siluridae, reveal significant differences that can be attributed to differences in their feeding habits, differences in water temperatures, other environmental factors and to genetic factors, thereby suggesting common biodiversity.

This study will also enrich the consciousness about the nutritional value of these two edible fishes and will also contribute some important information in fishery science.

\section{References}

1. Talwar P.K.; Jhingran, A.G. Inland fishes of India and adjacent countries 2, Oxford and IBM publishing Co. Pvt. Ltd. New Delhi. pp. 579-591 (1991).

2. Sargent, J.R.; Henderson, R.J.; Tocher, D.R. The lipids. 
in Fish Nutrition. (Halver, J.E. ed.). Academic Press. New York. pp. 153-218 (1989).

3. Fraser, A.J.; Sargent, J.R.; Gamble, J.C.; Maclachlan, P. Lipid class and fatty acid composition as indicators of the nutritional condition of Larval Atlantic herring. Am. Fish. Soc. Symp. 2, 129-143 (1987).

4. Fraser, A.J. Triacylglycerol content as a condition index for fish, bivalve and crustacean larval. Can. J. Fish. Aquat. Sci. 46, 1868-1873 (1989).

5. Watanabe, T.; Takuechi, T.; Saito, M. Effect of low protein high calorie or essential fatty acids deficiency diet on reproduction of rainbow trout. Bull. Jpn. Soc. Fish 50, 1207-1245 (1984).

6. Navas, J.M.; Bruce, M.; Thrush, M.; Farndale, B.M.; Bromage, N.; Zanuy, S.I.; Carrillo, M.; Bell, G.J.; Ramos, J. The impact of seasonal alternation in the lipid composition of broodstock diets on egg quality in the European seabass. J. Fish Biol. 51, 760-773 (1997).

7. Rodriguez, C.; Cejas, J.R.; Martin, M.V.; Badia, P.; Samper, M.; Lorenzo, A. Influence of n-3 highly unsaturated fatty acid deficiency on the lipid composition of brood stock gilthead seabream (Sparus aurata) and on egg quality. Fish Physiol. Biochem. 18, 177-187 (1998).

8. Evans, R.P.; Parrish, C.C.; Brown, J.A.; Davis, P.J. Biochemical composition of eggs from repeat and firsttime spawning captive Atlantic halibut (Hippoglossus hippoglossus), Aquaculture 139, 139-149 (1996).

9. Rainuzzo, J.R.; Reitan, K.I.; Jorgensen, L. Comparative study on the fatty acid and lipid composition of four marine fish larvae. Comp. Biochem. Physiol. 103B, 2126 (1992).

10. Parrish, C.C.; Brown, J.A.; Daniel, E.S.; Somerton, D.C. Fatty acid composition of Atlantic halibut eggs in relation to fertilization. Bull. Aquacult. Assoc. Canada 94, 36-38 (1994).

11. Bell, J.G.; Farudale, B.M.; . Bruce, M.P.; Navas, J.M.; Carillo, M. Effects of broodstock dictary lipid on fatty acid compositions of eggs from sea bass (Dicentrarchus labrax). Aquaculture 149, 107-119 (1997).

12. Fraser, A.J.; Gamble, J.C.; Sargent, J.R. Changes in lipid content, lipid class and fatty acid composition of developing eggs and unfed larval cod (Gadus morhua). Mar. Biol. 99, 307-313 (1988).

13. Sargent, J.R.; Bell, J.G.; Bell, M.V.; Henderson, R.J.; Tocher, D.R. The metabolism of phospholipids and polyunsaturated fatty acids in fish in coastal and estuarine studies. in Aquaculture; Fundamental and applied research (Lahlou, B; Vitiello, P. ed.). American Geophysical Union. Washington DC. pp. 103-124 (1994).

14. Folch, J.; Lees, M.; Solane-Stanley, G.H. A simple method for the isolation purification of total lipids from animal tissues. J. Biol. Chem. 226, 497-509 (1957).

15. A. O. C. S. Official method and recommended practice of Am. Oil Chem. Soc. Method No. Ja-7-86 (Total Phospholipid); Ca-12-55 (Phospholipid fraction) $4^{\text {th }}$ Edn. (Firestone, D. ed.). Washington DC (1991).

16. Zlatkis, A.; Zak, B.; Boyele, A.J. J. Lab. Clin. Med. 41, 486 (1953).

17. Christie, W.W. Lipid analysis, Pergamon press, Oxford, UK (1982).

18. Mukhopadhyay, T.; Ghosh, S. Lipid profile and fatty acid composition of eggs of common carp (Cyprinus carpio). J. Oleo. Sci. 52, 439-442 (2003).

19. Biometrica Tables for Statisticians (Pearson, S.; Hartley, H.O. ed.) Cambridge, Vol.1, Table 12 (1966).

20. Field F.J;; Mathur, S.N. Intestinal lipoprotein synthesis and secretion. Prog. Lipid Res. 34, 185-198 (1995).

21. Fontagne, S.; Geurden, I.; Escaffre, A.M.; Bergot, P. Histological changes induced by dietary phospholipids in intestine and liver of common carp (Cyprinus carpio L.) Larvae. Aquaculture 161, 213-223 (1998).

22. Yamada, K.; Kobayashi, K.; Yone, Y. Conversion of linolenic acid to $\omega$-3 highly unsaturated fatty acids in marine fishes and rainbow trout. Bull. Jpn. Soc. Sci. Fish 46, 1231-1233 (1980).

23. Takeuchi, T.; Watanabe,T. The effects of starvation and environmental temperature on proximate and fatty acids composition of carp and rainbow trout. Bull. Jpn. Soc. Sci. Fish 48, 1307-1316 (1982).

24. Castell, J.D.; Bell, J.G.; Tocher, D.R.; Sargent, J.R. Effects of purified diets containing different combinations of arachidonic and docosahexaenoic acid on survival, growth and fatty acid composition of juvenile turbot (Scophthalmus maximus). Aquaculture 128, 315-333 (1994).

25. Falk-Peterson, S.; Falk-Peterson, I.B.; Sargent, J.R.; Thaug, T. Lipid class and fatty acid composition of eggs from the Atlantic halibut (Hippoglossus hippoglossus). Aquaculture 52, 207-211 (1989). 